\title{
Competitive Strategy and Performance in Mexico, Peru, and the United States
}

Article in Journal of CENTRUM Cathedra · April 2011

DOI: 10.7835/jcc-berj-2010-0044

CITATION

1

1 author:

\section{John Alan Parnell}

University of North Carolina at Pembroke

130 PUBLICATIONS $\quad 2,007$ CITATIONS

SEE PROFILE
READS

82

Some of the authors of this publication are also working on these related projects: 


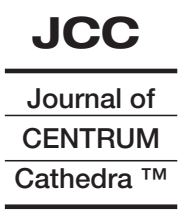

\title{
Competitive Strategy and Performance in Mexico, Peru, and the United States
}

\author{
by \\ John A. Parnell \\ Ph.D. in Business Administration, University of Memphis, USA \\ Belk Chair of Management, School of Business Administration, University of North Carolina \\ at Pembroke, USA
}

\begin{abstract}
This paper compares competitive strategy-performance relationships in Mexico, Peru, and the USA. 334 managers in the USA, 398 in Mexico, and 314 in Peru completed surveys. An innovative strategy orientation was positively associated with performance satisfaction in all three nations. The link between low cost strategy orientation and performance was negative in Mexico and positive in the USA. Mexican firms were the most innovative and Peruvian the most cost-oriented. Top managers in Mexico considered their firms' strategies less innovative and more cost-oriented than did middle and lower level managers. Top managers in Peru considered their firms' strategies more cost-oriented than did middle and lower level managers. The U.S. sample showed no significant strategy differences across management levels.
\end{abstract}

Keywords: business strategy, competitive strategy, Mexico, performance, Peru

\section{Introduction}

The competitive strategy-performance relationship has been a prevalent research topic over the past three decades. During this time, however, most published work considered firms and industries in the United States and other developed nations. In contrast, emerging economies have received considerably less attention, although current efforts have begun to address this problem. This paper adds to our knowledge of competitive strategies in emerging nations by comparing and contrasting the nature of the strategy-performance link in Mexico, Peru, and the United States. Specifically, this paper examines the extent to which differences in the strategy-performance relationship exist among the three nations, with additional consideration given to the influence of management level on strategy perceptions.

The remainder of the paper includes a brief historical depiction of the competitive strategy literature and an overview of general management practice in Mexico and Peru. Hypotheses are presented, followed by discussions of research methods and findings. Conclusions and implications for management practice and research are also suggested.

\section{Competitive Strategy and Performance}

The nature of the competitive strategy-firm performance relationships can be traced to Bain (1956) and Mason's (1939) industrial organization framework of industry behavior, whereby firm profitability is viewed primarily as a function of industry structure. Characteristics of the industry - not the organization - are the key influences on organizational performance (Barney, 1986). Early strategy research- 
ers challenged the I/O perspective, noting its inability to explain large performance variances within a single industry (Ghemawat, 2002). Initially, case studies highlighted firm-level behaviors associated with performance that were not readily explained by industry-level analyses.

The strategic group level of analysis was proposed as a compromise between I/O's deterministic, industry level of analysis and the organization level of analysis inherent to the strategic management discipline (Hergert, 1983; Porter, 1981). Strategic groups describe apparent clusters of businesses that appear to exhibit homogeneous behavior within a heterogeneous industry. Because strategic group assessments identified clusters of businesses employing largely similar strategies, researchers began to categorize likenesses within the strategic groups across studies. Business strategy typologies-also referred to as gestalts, frameworks, and archetypes-were proposed, each identifying several generic strategic approaches. In general, the literature supports the notion that various competitive strategies influence firm performance in different ways (Hashim, 2000; Porter, 1980; Slater \& Narver, 1993).

The generic strategy typologies proposed in the late 1970s and 1980s became the theoretical basis for identifying strategic groups in industries. Porter's (1985) generic strategy typology is the most widely referenced. Following Porter, a business can maximize performance either by striving to be the low cost producer in an industry or by differentiating its line of products or services from those of other businesses; either of these two approaches can be accompanied by a focus of organizational efforts on a given segment of the market.

Porter (1980) suggested that a business attempting to combine the two approaches invariably ends up stuck in the middle. He argued that the low cost and differentiation strategies are based on incompatible assumptions and thereby create trade-offs within the organization. This notion received considerable initial support (Dess \& Davis, 1984; Hambrick, 1981; Hawes \& Crittendon, 1984), but it was later challenged by a substantial body of research (Parnell, 1997; Parnell \& Wright, 1993; Proff, 2000; White, 1986; Wright, 1987). Members of the "combination strategy school" have argued that businesses successfully combining low costs and differentiation may create synergies within the firm that overcome any trade-offs that may be associated with the combination.

A second typology, Miles and Snow's (1978) generic strategy approach, identified four competitive strategy alternatives: prospectors, analyzers, defenders, and reactors. The first three of these strategies can be associated with high performance if the organization's approach is aligned with the demands of its environment. A fourth strategy type - the reactor — does not represent a high-performing strategy, a conceptualization consistent with the notion of strategic simplicity (Lumpkin \& Dess, 2006; Miller \& Dess, 1993). Research has supported the validity of the Miles and Snow typology, although there have been some inconsistencies in findings (DeSarbo, DiBenedetto, Song, \& Sinha, 2005; Hambrick, 1983; Parnell, 2000; Parnell \& Wright, 1993; Segev, 1987; Zahra \& Pearce, 1990).

Although these typologies emphasized the strategy similarities inherent in strategic group level research, Porter's combination strategy debate and Miles and Snow's notion of an analyzer-also viewed by some as a hybrid strategy — underscored the strategic differences across firms as well. If two generic strategies can be combined effectively, then various combinations become feasible. Following this logic, the low cost and differentiation generic strategies may be conceptualized as opposite ends of a continuum rather than as distinct, mutually exclusive strategic approaches. Hence, the strategic group level of analysis not only emphasized strategy commonalities within industries but inevitably exposed the shortcomings of strategic groups as well.

Discontent with the limited emphasis placed on organization-specific factors in strategic group analysis and strategy typologies may have been the primary impetus for a renewed interest in firm resources, not strategic group membership, as the foundation for firm strategy (Barney, 1986, 1991; Camerer \& Vepsalainen, 1988). The resulting paradigm, resource-based theory, emphasizes unique firm capabilities, competencies, and resources in strategy formulation, implementation, and performance (Dutta, Narasimhan, \& Rajiv, 2005; Kor \& Mahoney, 2005). Indeed, the resource-based perspective is largely supported by a substantial body of empirical literature (Ray, Barney, \& Muhanna, 2004). Resource-based scholars have studied such firm-level issues as transaction costs, economies of scope, and organizational culture (Barney, 1991; Camerer \& Vepsalainen, 1988; Fiol, 1991). Prominent businesslevel issues include the analysis of competitive imitation (Rumelt, 1984), informational asymmetries (Barney, 1995), causal ambiguities (Reed \& DeFillippi, 1990), and resource accumulation (Dierickx \& 
Cool, 1989). Sustained competitive advantage is a key focal point and exists when competitors are unable to duplicate the benefits of the strategy (Barney, 1991).

Recently, organizational economics - integrating perspectives such as agency theory, incentives, transaction cost theory, and property rights theory-has experienced a resurgence in the literature (Foss \& Foss, 2005; Fulghieri \& Hodrick, 2006; Gibbons, 2003; Whinston, 2003). In many respects, this perspective represents an extension of the resource-based perspective. Scholars in the organizational economics school integrate the tools and theories originally established for the industry level of analysis with new insights and approaches more appropriate for the firm level (Sheehan \& Foss, 2007). The organizational economics perspective sheds new light on the issue by viewing top management as a key resource to be attracted, developed, and harvested. By incorporating transaction costs, agency theory, and other corporate governance concerns into the analysis, scholars are expanding the boundaries of the competitive strategy field (Boxall \& Gilbert, 2007). Organizational economics therefore offers the potential for an integrative, comprehensive framework for understanding strategies in organizations (Kim \& Mahoney, 2005).

Although the three major streams of competitive strategy-performance research-I/O economics, strategic groups, and resource-based theory-differ markedly in their assumptions concerning organizational performance, they see firm performance primarily as a function of firm behaviors, either individually or collectively. The increasing interest in firm resources, however, does not mean that testing strategy typologies is no longer useful, especially in emerging economies where such testing has been limited (Kim, Nam, \& Stimpert, 2004; Kimura \& Mourdoukoutas, 2000; Leiblein, 2003; Parnell, 2008; Pitelis \& Pseiridis, 1999). In addition, the pace and intensity of change in the global business environment have become much more pronounced during the past two decades. As a result, speed has become more valuable as a competitive weapon, while the Internet has minimized the importance of physical boundaries and distance, and can enable firms to serve larger markets more efficiently (Kim et al., 2004).

\section{Historical Context: Mexico and Peru}

The present study examines strategic behavior in two emerging Latin American nations, Mexico and Peru. The two countries are similar, yet culturally diverse. Mexico offers a blend of several cultures including the indigenous Amerindian peoples, the Spanish, and various other societal groups. The culture itself can be considered cohesive, and the family is very important in life and in making decisions. In addition, Mexican culture - and specifically Mexican business practice - has been influenced substantially by its neighbor to the north. American business investment in Mexico has soared over the past decade despite the 1994 Mexican financial crisis (Bieber \& Mukhtyar, 1999). The prospects for continued growth of Mexican exports to the United States and Canada are strong (Ahmed, d'Astous, \& Lemire, 1997; De La Garza, 2007; Hise, Solano-Mendez, \& Gresham, 2003), political negotiations and confrontations notwithstanding (Dominguez-Villalobos \& Brown-Grossman, 2007).

Unlike employees in the United States, Mexican employees value status differentials between individuals and expect their observance when appropriate (Stinson, 1995). Class distinction is widely accepted, as is the great difference in the distribution of wealth and power within organizations. Influence from the United States notwithstanding, there is evidence that Mexican managers employ substantially different reasoning processes from their American counterparts (Husted, Dozier, McMahon, \& Kattan, 1996; Lowe, Morris \& Wilkinson, 2000). Overall, the Mexican culture is cohesive, one that emphasizes the role of the family. Decision-making authority tends to be centralized in Mexico, with little delegation (Morris \& Pavett, 1992; Schniederjans \& Zuckweiler, 2004). Although the business work system has tended to be patriarchal, Mexican workers tend to be very loyal to their organizations. However, a shift toward a free flow of information, employee participation, and decentralization can also be seen in Mexican organizations (Morales, 1997). Even the notion of self-managed work teams has gained attention among Mexican organizations (DeWitt, 1995; Schniederjans \& Zuckweiler, 2004; Stephens \& Greer, 1995).

Like Mexico, Peru has deep linkages to its history and indigenous culture. Although the Spanish and Amerindian influences are predominant, many Peruvians trace their ancestry to Japan and other parts of Asia. Peru is South America's third largest country and has an economy composed of modern and subsistence sectors, with the former most prominent in its predominant urban center, Lima (Economist Intelligence Unit, 2003). The proportion of women in the urban workforce grew from about one third in 1970 to about one half by 2000 (Sully De Luque \& Arbazia, 2005). 
Peruvian managers tend to possess a greater tolerance for role ambiguity and preference for a lower power distance between superiors and subordinates than their counterparts in the United States (Sully De Luque, 2000). Hence, there appears to be a trend in favor of greater management interaction, greater decentralization of decision making, and more participative leadership styles (Buchenrieder \& Heuft, 2003). Peruvian management practice is difficult to encapsulate, however, because of substantial differences across firms and industries. Indeed, formal human resource practices only became apparent in the early 2000s (Sully De Luque \& Arbazia, 2005).

Mexico and Peru are often referenced as part of a larger emerging Latin American cluster of nations. Substantial cultural, structural, and economic differences exist among these nations, (Husted \& Allen, 2006; Kumar \& Chase, 2006). Further, some of the differences between the two nations are difficult to assess because of considerable differences within each of them. Such differences exist throughout Mexico, particularly when one compares the developing industrial cities along the U.S. border and the nation's capital with smaller, more isolated cities and small communities in outlying regions. This problem is particularly pervasive in Peru, however, where management practice is difficult to encapsulate because of substantial differences across geographical regions, firms, and industries (Jackle \& Li, 2006). Indeed, formal human resource practices only became apparent last decade, and are most visible in large firms in Lima (Sully de Luque \& Arbazia, 2005). While management practice at large Peruvian firms is more likely to reflect current thinking, Peru has an unusually high percentage of small- and medium-sized enterprises (SMEs). In 2002, only 13\% of organizations in metro-Lima employed 50 or more workers (Ministerio de Trabajo y Promocion del Empleo, 2003). Activity in the informal economy is substantial, however, especially outside of Lima. Such workers may run factories in their homes, operate a small shop, or function as street vendors.

Historically, working conditions in Peru have been challenging. Legislation in the 1970s addressed these concerns, opening the door to collective bargaining practices designed to protect basic worker rights. Since that time, labor union movements in Peru have been common, frequently accompanied by tense management-labor relations (Collier \& Collier, 1991; Graham, 2001; Haworth, 1989). Strikes were common in the late 1980s, a factor many believe contributed to a severe economic downturn in the 1990s. As a result, an economic restructuring plan that included market-oriented reforms, a stronger central government, and weaker unions was instituted (Cameron \& Mauceri, 1997; Parodi, 2000). The shift away from protectionism and high tariffs - as well as the elimination of two powerful guerilla organizations - resulted in substantial economic gains (EIU, 2003; Kay, 1997; Palmer, 1992). Hence, workforce cohesion - not strategic management-was an overriding concern of many top managers in Peru until the first decade of the 21 st century.

\section{Hypotheses}

Four hypotheses are proposed in this present study. Justification for each hypothesis is elaborated herein.

A large volume of extant research assesses the link between competitive strategy and performance. Specifically, the literature is replete with strategic group assessments associating innovation- and/or cost-oriented strategies with performance (Nicholson, Rees, \& Brooks-Rooney, 1990). Many of these studies have been conducted within the context of generic strategy typologies developed by Porter (1980, 1985) and Miles and Snow (1978).

Porter's $(1980,1985)$ framework suggests that a business can maximize performance by striving to be the low cost producer in an industry or by differentiating its line of products or services from those of its rivals. Miles and Snow's (1978) framework identified four strategic types: prospectors, defenders, analyzers, and reactors. Prospectors represent innovative businesses and perceive the environment as dynamic and uncertain, maintaining flexibility and employing innovation to combat environmental change and often becoming the industry designers (Miles \& Snow, 1986). Defenders perceive the environment to be stable and certain, and they seek stability and control in their operations to achieve maximum efficiency (Brunk, 2003). Hence, both typologies present innovative and low cost strategic alternatives. Empirical work testing both typologies has largely supported positive links between both approaches and performance (Allen \& Helms, 2006; Moore, 2005; Morgan \& Berthon, 2008; O'Regan \& Ghobadian, 2006). Although such tests in developing nations are not as plentiful, similar links would be expected in the United States, as well as in Mexico and Peru. 
H1a: An innovative strategy orientation is positively associated with performance satisfaction. $\mathrm{H1b}$ : A low cost strategy orientation is positively associated with performance satisfaction.

Hofstede's (1980, 1993, 2003, 2004) cultural dimensions can be utilized as part of the theoretical foundation for comparing and contrasting the United States, Mexico, and Peru. His individualism (IDV) index represents the extent to which a society's members tend to function as individuals rather than members of groups. Collectivism - not necessarily in the political context-is the opposite of Hofstede's conceptualization of individualism. Both Mexico and Peru produced low scores on the IDV, 30 and 16 respectively, whereas the USA produced a score of 91. From a management perspective, a low IDV can have both positive and negative influences on productivity. Low individualism means less individual initiative and even groupthink, however, as individuals are hesitant to express unpopular opinions. Individualism has been linked to innovation and strategic decision making (Duimering \& Robinson, 2009; Martin-Alcazar, Romero-Fernandez, Sancez-Gardey, \& Sanchez-Perez, 2009).

H2a: U.S. firms emphasize innovation more than do Mexican firms.

H2b: Mexican firms emphasize innovation more than do Peruvian firms.

A large body of extant strategy-performance literature is based on the notion that a strategy tailored to a firm's internal and external environment is more likely to result in superior performance (Brouthers \& Arens, 1999; Hamilton \& Shergill, 1992; Zajac, Kraatz, \& Bresser, 2000). Within this context, strategic management helps organizations cope with uncertainty by helping shape the competitive environment (Das, Handfield, Calantone, \& Ghosh, 2000). The strategy selected by each organization determines the means by which it intends to successfully meet competitive challenges (Porter, 1980). Better information and certainty about the environment tend to improve performance (Katz, Zarkeski, \& Hall, 2000; Thompson, 1967).

Hofstede's uncertainty avoidance index (UAI) reflects the extent to which members of a particular society tolerate uncertainty and ambiguity. More specifically, it suggests the degree of comfort one is likely to have when operating in unstructured situations. Whereas the United States scores relatively low on the UAI - 46-Mexico and Peru score much higher, with scores of 81 and 87 respectively. In both nations, high uncertainty avoidance is pervasive, both throughout society and in organizations. Decision making tends to be centralized in these Latin American nations, with little delegation of authority (Morris \& Pavett, 1992).

Because of differences in human, environmental, and technological resources, Latin American firms often face different strategic challenges when compared to their American and European counterparts (Correa, 2007; Ickis, 2000). Innovation represents a key link between uncertainty and strategy. The innovative process assumes the existence of uncertainty and seeks to leverage it through productive change. Given the Mexican and Peruvian tendency to avoid uncertainty, Mexican and Peruvian firms will reflect a greater emphasis on low costs than those in the United States.

H3a: Peruvian firms emphasize a low cost orientation more than do Mexican firms. H3b: Mexican firms emphasize a low cost orientation more than do U.S. firms.

Strategy is both an actualized and a perceived phenomenon, and manager perceptions can depend on individual responsibilities. Top managers, for example, are more conceptually oriented and are more likely to appreciate the innovative nature of strategy. Strategy is a human issue, however, particularly when execution is involved (Goldman, 2003; Ostroff \& Atwater, 2003). Middle-level managers play a significant role in this process, both with their contribution to strategy content and their sensemaking and dissemination of the strategy throughout the organization (Bonn, 2005; Floyd \& Wooldridge, 2000; Gioia \& Chittipeddi, 1991). Middle managers often report dissatisfaction with the amount of top management support for their strategy execution efforts (Qi, 2005). Indeed, it is difficult to overstate their role in successful implementation (Balogun \& Johnson, 2005; Embertson, 2006).

Research supports the notion that effective strategy formulation and execution often reflect a diverse array of top and middle management inputs (Antonioni, 1999; Currie, 1999; Davis, 2001; Thakur, 1998; Yoo, Reed, Shin, \& Lemak, 2009). Mintzberg and Waters' (1985) conceptualization of deliberate and emergent strategies acknowledges the prominent role top and middle managers play in the strategic management process. Following the work of Burgelman (1983) and Hiam (1993), Nichol (1992) observed that top management simply cannot effectively develop a strategy and plan for its imple- 
mentation without assistance from middle managers. Hence, middle managers - more concerned with execution - tend to emphasize and balance top management's concern for conceptual issues with a more practical concern for control. This distinction becomes even more apparent when lower level managers are considered.

\section{H4a: Top managers perceive their firms'strategies as more innovative than do middle and lower level managers.}

H4b: Lower level managers perceive their firms'strategies as more cost-focused than do middle and upper level managers.

\section{Methods}

To test the hypotheses, it was necessary to measure strategic orientation along the lines of innovation and cost leadership. Measuring organizational performance was also necessary, and doing so always represents a challenge in strategy-performance studies, as measurement choices can influence findings (Cavalieri, Gaiardelli, \& Ierace, 2007; Jusoh \& Parnell, 2008; Pongatichat \& Johnston, 2008). Performance is an elusive construct and can be evaluated from a narrow, profit-oriented viewpoint or from a broader perspective that also includes considerations such as market share, firm growth, and the attainment of organizational objectives. A broad conceptualization of performance is utilized in the present study.

Quantitative measures of organizational performance can be employed, but a qualitative approach can assess subjective areas of performance such as the satisfaction of managers, customers, and other stakeholders and ethical behavior. Moreover, utilizing a qualitative approach provides insight into organizational processes and outcomes that may not be readily apparent when financial measures are evaluated (Ayadi, Dufrene, \& Obi, 1996; Parnell, O’Regan, \& Ghobadian, 2006). A qualitative assessment was utilized in the present study, adopting a self-typing scale to assess relative competitive and objective performance from Parnell, Lester, and Menefee (2000).

The instrument utilized in this study contained Pelham and Wilson's (1996) five-item innovation strategy and three-item low cost strategy scales and Parnell, Lester, and Menefee's (2000) five-item performance satisfaction scale (see also Parnell, 2004; Parnell, O’Regan, \& Ghobadian, 2006). Demographic and personal items were also added, including age, gender, management experience, organizational experience, and position (i.e., management level) in the firm. Survey details are provided in Table 1.

Table 1

Explanation of Survey Items

\begin{tabular}{|c|c|}
\hline Item & Concern \\
\hline STRATINN1 & New product developmen $\mathrm{t}$ \\
\hline STRATINN2 & Strict product quality control procedures \\
\hline STRATINN3 & Developing new products and refining existing ones \\
\hline STRATINN4 & Innovation in the manufacturing process \\
\hline STRATINN5 & Developing products for higher priced markets \\
\hline STRATCOST1 & Pricing below competitors \\
\hline STRATCOST2 & Continuous, overriding concern for lowest cost per unit of production \\
\hline STRATCOST3 & Production for lower priced market segments \\
\hline PERSAT1 & Satisfaction with operating profits \\
\hline PERSAT2 & Satisfaction with profit to sales ratio \\
\hline PERSAT3 & Satisfaction with cash flows from operations \\
\hline PERSAT4 & Satisfaction with return on investment \\
\hline PERSAT5 & Satisfaction with return on assets \\
\hline
\end{tabular}


Surveys were completed by 334 managers in post-graduate training programs in the United States. The survey was also translated into Spanish and completed by 398 Mexican and 314 Peruvian managers in post-graduate programs in their respective countries. All surveys were administered by the author of the study. The sample included a variety of industrial classification and orientations in all three nations. All three management levels were represented in each sample, although the U.S. sample contained a relatively higher percentage of top managers. The average age of respondents ranged from 31.3 years in Peru to 36.5 years in the United States. Likewise, respondents in Mexico and the United States tended to have more management and organizational experience than did their Peruvian counterparts. A summary of key sample data is presented in Table 2.

Table 2

The Sample

\begin{tabular}{lccc}
\hline \multicolumn{1}{c}{ Frequencies } & $\begin{array}{c}\text { Mexico } \\
(n=292)\end{array}$ & $\begin{array}{c}\text { Peru } \\
(n=314)\end{array}$ & $\begin{array}{c}\text { United States } \\
(n=334)\end{array}$ \\
\hline \multicolumn{1}{c}{ Gender* } & & & \\
Men & $192(65.8 \%)$ & $151(48.1 \%)$ & $152(42.6 \%)$ \\
Women & $100(34.2 \%)$ & $163(51.9 \%)$ & $191(57.4 \%)$ \\
$\quad$ Management level & $100(34.2 \%)$ & $136(43.3 \%)$ & $120(35.9 \%)$ \\
Lower managers & $144(49.3 \%)$ & $144(45.9 \%)$ & $114(34.1 \%)$ \\
Middle managers & $48(16.4 \%)$ & $34(10.8 \%)$ & $100(29.9 \%)$ \\
Top managers & & & \\
$\quad$ Descriptive data (mean \& standard deviation) & $33.26(S D=5.68)$ & $31.27(S D=5.83)$ & $36.47(S D=10.67)$ \\
Age & $6.82(S D=4.82)$ & $3.63(S D=2.87)$ & $7.02(S D=7.96)$ \\
Management experience & $7.01(S D=4.02)$ & $4.08(S D=2.80)$ & $6.89(S D=7.40)$ \\
Experience with organization &
\end{tabular}

*One U.S. respondent did not select a gender.

\section{Results}

Scale validation was necessary prior to testing the hypotheses. One-factor solutions for the innovation, cost, and performance satisfaction scales are presented in Table 3. The innovation and cost items were factor-analyzed as a group to confirm the existence of two strategic orientations. Innovation and cost items were expected to coalesce into two relatively distinctive factors in each national sample. If this did not happen, questions of discriminant validity could be raised.

Two-factor, Varimax-rotated solutions for innovation and cost items for Mexico, Peru, and the United States are presented in Tables 4-6 respectively. Factor loadings are strong in most instances with two exceptions. The third cost item-production for lower priced market segments—-did not load well in either the Mexican or Peruvian samples (see Table 3). Likewise, the fifth innovation item - production for higher priced market segments-was viewed more as anti-cost than pro-innovation in the Mexican sample (see Table 4). Collectively, these anomalies suggest that the presumed link between low (production) costs and low (market) price remains strong in the United States, but this phenomenon is not necessarily shared in Mexico and Peru. 
Table 3

Factor Analysis of the Strategy Innovation, Cost Leadership, and Performance Satisfaction Scales

\begin{tabular}{|c|c|c|c|}
\hline & $\begin{array}{l}\text { Mexico } \\
(n=292)\end{array}$ & $\begin{array}{c}\text { Peru } \\
(n=314)\end{array}$ & $\begin{array}{l}\text { United States } \\
\qquad(n=334)\end{array}$ \\
\hline \multicolumn{4}{|l|}{ Strategy innovation } \\
\hline STRATINN1 & .782 & .741 & .824 \\
\hline STRATINN2 & .649 & .809 & .824 \\
\hline STRATINN3 & .738 & .823 & .835 \\
\hline STRATINN4 & .659 & .717 & .772 \\
\hline STRATINN5 & .526 & .737 & .709 \\
\hline Alpha & .699 & .822 & .852 \\
\hline Variance explained & $45.76 \%$ & $58.72 \%$ & $63.09 \%$ \\
\hline \multicolumn{4}{|c|}{ Strategy cost leadership } \\
\hline STRATCOST1 & .854 & .808 & .814 \\
\hline STRATCOST2 & .828 & .857 & .867 \\
\hline STRATCOST3 & .483 & .310 & .861 \\
\hline Alpha & .557 & .463 & .803 \\
\hline Variance explained & $54.95 \%$ & $49.46 \%$ & $71.82 \%$ \\
\hline \multicolumn{4}{|c|}{ Performance satisfaction } \\
\hline PERSAT1 & .741 & .638 & .838 \\
\hline PERSAT2 & .709 & .953 & .843 \\
\hline PERSAT3 & .808 & .839 & .834 \\
\hline PERSAT4 & .737 & .917 & .894 \\
\hline PERSAT5 & .657 & .872 & .870 \\
\hline Alpha & .772 & .897 & .909 \\
\hline Variance explained & $53.59 \%$ & $72.43 \%$ & $73.48 \%$ \\
\hline
\end{tabular}

Table 4

Mexico: Two-Factor Solution for Innovation and Cost Items

\begin{tabular}{lcc}
\hline & Strategy emphasis innovation & Strategy emphasis cost \\
\hline STRATINN1 & .495 & -.595 \\
STRATINN2 & .748 & -.081 \\
STRATINN3 & .582 & -.461 \\
STRATINN4 & .769 & -.043 \\
STRATINN5 & .079 & -.732 \\
STRATCOST1 & -.070 & .868 \\
STRATCOST2 & -.247 & .715 \\
STRATCOST3 & .344 & .430 \\
\hline
\end{tabular}

Table 5

Peru: Two-Factor Solution for Innovation and Cost Items

\begin{tabular}{lcc}
\hline & Strategy emphasis innovation & Strategy emphasis cost \\
\hline STRATINN1 & .748 & -.208 \\
STRATINN2 & .807 & .153 \\
STRATINN3 & .783 & .320 \\
STRATINN4 & .713 & .043 \\
STRATINN5 & .747 & -.035 \\
STRATCOST1 & .092 & .779 \\
STRATCOST2 & -.345 & .827 \\
STRATCOST3 & .226 & .370 \\
\hline
\end{tabular}


Table 6

United States: Two-Factor Solution for Innovation and Cost Items

\begin{tabular}{lcc}
\hline & Strategy emphasis innovation & Strategy emphasis cost \\
\hline STRATINN1 & .796 & .212 \\
STRATINN2 & .853 & .026 \\
STRATINN3 & .853 & .059 \\
STRATINN4 & .690 & .360 \\
STRATINN5 & .653 & .252 \\
STRATCOST1 & .156 & .782 \\
STRATCOST2 & .198 & .836 \\
STRATCOST3 & .121 & .853 \\
\hline
\end{tabular}

Given the general support of the innovation, cost, and performance satisfaction scales, composite single-factor solutions were generated for the innovation, cost, and performance satisfaction scales. Factor scores via the regression method were computed to serve as surrogates for each for hypothesis testing.

The first hypothesis was partially supported. A positive correlation between an innovative strategy orientation and performance satisfaction was found in all three nations. A positive link between a low cost strategy orientation and performance satisfaction was found only in the United States. This link was not significant in Peru and was negative in Mexico (see Table 7).

Table 7

Strategy Associations with Performance Satisfaction

\begin{tabular}{lccc}
\hline \multirow{2}{*}{ Variable } & & Factor scores & \\
& Mexico & Peru & United States \\
\hline Strategy innovation & $.469^{*}$ & $.713^{*}$ & $.260^{*}$ \\
Strategy cost & $-.447^{*}$ & .072 & $.254^{*}$ \\
\hline
\end{tabular}

* significant at .05 level

Hypothesis $2 a$ was not supported, but hypothesis $2 b$ was supported. Mexican firms were viewed as the most innovative of the three groups. Firms in the United States were viewed as the least innovative. Results from an analysis of variance (ANOVA) of strategy comparisons across nations appear in Table 8.

Table 8

Nation Comparisons

\begin{tabular}{lccccc}
\hline Variable & \multicolumn{5}{c}{ Factor scores } \\
& Mexico & Peru & United States & F-value & Significance \\
\hline Strategy innovation & .499 & -.143 & -.308 & 62.406 & .000 \\
Strategy cost & -.471 & .363 & .077 & 60.964 & .000 \\
Performance satisfaction & .407 & -.039 & -.327 & 46.064 & .000 \\
\hline
\end{tabular}

Hypothesis $3 a$ was supported, but hypothesis $3 b$ was not supported. Peruvian firms were seen as the most cost-oriented of the three groups. Mexican firms were viewed as the least cost-oriented, however, with U.S. firms scoring in the middle.

Hypothesis 4a was supported in Peru only, whereas hypothesis $4 b$ was not supported. In Mexico, lower level managers viewed their strategies as most innovative, whereas top managers viewed them as most cost-focused. Peruvian top managers also emphasized cost-oriented strategies more than managers at other levels. No significant difference was found among Peruvian managers with respect to innovative strategies. Interestingly, no significant differences were found across managers in the United States, 
either in terms of innovation or cost. ANOVA results are presented in Table 9.

Table 9

Strategic Emphasis Comparisons by Management Level

\begin{tabular}{lccc}
\hline & Mexico $(n=392)$ & Peru $(n=314)$ & United States $(n=334)$ \\
\hline Strategy innovation & & & \\
Lower management & .784 & -.137 & -.276 \\
Middle management & .545 & -.227 & -.306 \\
Upper management & .230 & .187 & -.346 \\
Total & .499 & -.143 & -.307 \\
F-statistic & 37.783 & 2.206 & 0.132 \\
Significance & .001 & .112 & .876 \\
Strategy cost & & & \\
Lower management & -.650 & -.061 & .048 \\
Middle management & -.512 & .516 & .110 \\
Upper management & .043 & 1.416 & .057 \\
Total & -.471 & .363 & .072 \\
F-statistic & 12.218 & 49.767 & 0.118 \\
Significance & .000 & .000 & .888 \\
\hline
\end{tabular}

\section{Discussion}

Results of the hypothesis testing were mixed. Before possible explanations can be proposed, it is important to acknowledge two limitations associated with the research design. First, all three samples included managers from a variety of industries. Hence, the influence of industry membership - if anycannot be detected in the present study.

Second, although sound research encourages one to maintain methodological consistency, problems invariably exist when constructs and surveys are modified or translated to suit samples in other cultures. Such changes invariably present judgmental decisions that must be made by the researcher. Punnett and Shenkar (1994) warned against interviews, experiments, and observational approaches where great religious and other cultural differences exist between the researcher's home culture and that being studied. In addition, survey research is feasible when any language barriers are overcome, but less reliable when educational differences are also highly pronounced. Further, one's values can influence item interpretation and create response bias.

This limitation may be discounted to some extent, however, because the U.S. sample scored between the Mexican and Peruvian samples along both low cost and innovation orientations. Language and cultural similarities between Mexico and Peru suggest that any such influence on results would likely have been shared by both nations. This lack of convergence between the Mexican and Peruvian samples notwithstanding, the influence of cultural and language bias remains a possibility.

Several explanations for the partial support for the hypotheses can be proffered. First, the perceptual nature of the research design is worth noting. For example, Mexican respondents were the most satisfied with the performance of their firms, followed by Peruvian and U.S. managers. This does not necessarily mean that actual performance was highest in the Mexican group. Rather, the relatively high performance satisfaction among Mexican respondents may be more closely associated with how actual performance compared to expected or past performance. It serves as a useful measure to assess the appropriateness of various strategy orientations within nations but has limited utility in terms of comparisons across borders.

Perceptions concerning strategies are more useful representations, especially when they are analyzed in concert. For example, one could question whether Mexico's high score along the innovation dimension might be associated with a proclivity among Mexican respondents to express a stronger 
agreement with strategy items than would their counterparts in other nations. In the instances of Mexico and Peru, however, this argument has little credence, as the same group of Mexican respondents that produced the highest innovation scores among the three groups also produced the lowest cost scores. Likewise, the Peruvian respondents produced the highest cost scores, but also generated scores below the mean in terms of innovation. Therefore, the existence of a general high or low score bias within the Mexican and Peruvian samples is unlikely.

These considerations notwithstanding, the present study challenges the traditional view that firms in developed nations - particularly the United States - tend to be the most innovative. Likewise, the notion that successful firms in emerging nations employ low cost strategies to facilitate the lowest possible prices is drawn into question as well.

It is also interesting to note the correlations among the factor score measures for innovation orientation, cost orientation, and performance satisfaction. Scores for the two strategy orientations were not significantly associated. The correlation between innovation and performance satisfaction was positive and strong (.556) and significant at the .000 level. The correlation between cost and performance satisfaction was negative but modest (-.065), significant at the .050 level. In other words, respondents who perceived their firms' strategies as more innovative were also likely to be satisfied with their firms' performance.

Although one might suggest a causal link between innovation and performance, such an inference might be premature. The notion that more innovative firms outperform less innovative ones is well documented in the literature (Dutta et al., 2005; Kor \& Mahoney, 2005). Nonetheless, strong performance can also create opportunities for innovation through increased market share and more slack resources (Cheng \& Kesner, 1997; Daniel, Lohrke, Fornaciari \& Turner, 2004). Hence, there is theoretical support for a reciprocal relationship between innovation and performance.

\section{Conclusions and Future Research}

The hypotheses tested in the present study received partial support. An innovative strategy orientation was positively associated with performance satisfaction in all three nations. A low cost orientation was positively associated with performance satisfaction in the United States, however, and the association was negative in Mexico and not significant in Peru. Mexican firms were found to be the most innovative, followed by Peruvian and U.S. firms. Peruvian firms were found to be the most costoriented, followed by U.S. and Mexican firms. Top managers in Mexico viewed their firms' strategies as less innovative and more cost-oriented than did middle and lower level managers. Top managers in Peru considered their firms' strategies to be more cost-oriented than did middle and lower level managers, with no differences found in terms of an innovation orientation. No significant strategy differences across management levels were found in the U.S. sample.

These findings raise questions about a widely accepted assumption about firms in emerging nations, specifically those in Latin America. Conventional wisdom suggests that successful firms in developed nations are more likely to pursue strategies anchored in innovation while those in emerging economies are more likely to emphasize cost containment (Parnell, 2004). This assumption was not supported in the present study.

Several opportunities for future research can be drawn from this study. First, increased investment in central and South American countries by United States' firms along with increased trade among businesses between these countries will broaden the impact of crises that occur. Stakeholders impacted by crises in all countries will find the world getting smaller. Understanding cultural differences and views can help managers manage the crisis events better.

Second, because many management constructs developed in advanced Western nations may be inappropriate in emerging economies, new constructs may more accurately explain management behavior (Punnett \& Shenkar, 1994). There is also a need for modified research approaches to compare and contrast practices among widely divergent cultures without forcing one culture into a construct definition appropriate in another. Researchers must seek applications of management concepts so that existing theory can be applied to developing countries while at the same time allowing for substantial theoretical 
modifications when findings cannot be readily explained by prevailing models (Brouthers, O’Donnell \& Hadjimarcou, 2005; Parnell \& Hatem, 1999).

Third, additional research on perceptual differences of strategy across management levels is needed. Wooldridge and Floyd's (1990) extensive empirical analysis of middle management strategic involvement found that middle management involvement in strategy formulation improved performance. Interestingly, most organizations represented in their sample deliberately involved middle managers in the process. Although their study reflects a culmination of thought acknowledging involvement beyond the top manager and even the top management team (Barker \& Patterson, 1996; Schilit, 1987), most published studies utilizing perceptual data continued to rely solely on the perceptions of the top manager (Goll \& Johnson, 1996).

Fourth, the present study did not evaluate differences with regard to firm size or industry. Indeed, small and large firms, as well as those in different industries, plan and execute strategies differently (Verreynne, 2006). This is a particular concern in Latin America where substantial qualitative differences exist between large global firms and small domestic ones (Jackle \& Li, 2006). For example, it is possible that for domestic firms in stable industries, low cost strategies may yield the highest performance levels. However, in dynamic, volatile industries common to Mexico and Peru, innovationoriented strategies may serve as a more effective means of adapting to unpredictable environmental changes. Additional work that examines the strategy-performance link in homogeneous groups based on size, scope, and structure is necessary. Without such research, generalizability across studies is tenuous (Morris \& Pavett, 1992; Sully De Luque \& Arbazia, 2005). This is a greater concern when considering non-Latin developing nations such as the Middle East or parts of Asia, but it is also relevant when addressing Latin America as a whole.

Finally_and broadly speaking_additional research in emerging nations is needed (Parnell \& Hatem, 1999). The lack of support for hypotheses proposed in this study underscores the fact that some widely held views concerning management in emerging economies may not hold up under empirical testing. Although scholars have begun to fill this void in recent years, a considerable amount of additional work is required.

\section{References}

Ahmed, S.A., d'Asous, A., \& Lemire, S. (1997). Country-of-origin effects in the U.S. and Canada: Implication for the marketing of products made in Mexico. Journal of International Consumer Marketing, 10, 73-92.

Allen, R. S., \& Helms, M. M. (2006). Linking strategic practices and organizational performance to Porter's generic strategies. Business Process Management Journal, 12, 433-454.

Antonioni, D. (1999). What motivates middle managers. Industrial Management, 41(6), 27-30.

Ayadi, O. G., Dufrene, U. B., \& Obi, C. P. (1996). Firm performance measurement: Temporal roadblock to innovation? Managerial Finance, 22, 18-22.

Bain, J. S. (1956). Barriers to new competition. Cambridge, MA: Harvard University Press.

Balogun, J., \& Johnson, G. (2005). From intended strategies to unintended outcomes: The impact of change recipient sensemaking. Organization Studies, 26, 1573-1601.

Barker, V. L., \& Patterson, P. W., Jr. (1996). Top management team tenure and top manager causal attributions at declining firms attempting turnarounds. Group and Organization Management, 21, 304-336.

Barney, J. B. (1986). Strategic factor markets: Expectations, luck, and business strategy. Management Science, 32, 1231-1241.

Barney, J. B. (1991). Firm resources and sustained competitive advantage. Journal of Management, 17, 99-120.

Barney, J. B. (1995). Looking inside for competitive advantage. Academy of Management Executive, 9(4), 49-61.

Bieber, S.M. \& Mukhtyar, M. (1999) Crisis management. Business Mexico. 8/9: 16.

Bonn, I. (2005). Improving strategic thinking: A multilevel approach. Leadership \& Organization Development Journal, 26, 336-354.

Boxall, P., \& Gilbert, J. (2007). The management of managers: A review and conceptual framework. International Journal of Management Reviews, 9(2), 95-115.

Brouthers, K. D., \& Arens, P. (1999). Privatization and strategic fit: Evidence from Rumania. Business Strategy Review 10(2), 53-59.

Brouthers, L. E., O’Donnell, E., \& Hadjimarcou, J. (2005). Generic product strategies for emerging market exports into triad nation markets: A mimetic isomorphism approach. Journal of Management Studies, 42, 225-245. 
Brunk, S. E. (2003). From theory to practice: Applying Miles and Snow's ideas to understand and improve firm performance. Academy of Management Executive, 17(4), 105-108.

Buchenrieder, G., \& Heuft, A. (2003). Decentralization in Peru's agriculture policy: A critical review from $1993-$ 1998. Oxford Development Studies, 31, 341-363.

Burgelman, R.A. (1983). Corporate entrepreneurship and strategic management. Management Science, 29, 13491364.

Camerer, C., \& Vepsalainen, A. (1988). The economic efficiency of corporate culture. Strategic Management Journal, 9, 115-126.

Cavalieri, S., Gaiardelli, P., \& Ierace, S. (2007). Aligning strategic profiles with operational metrics in after-sales service. Review of International Journal of Productivity and Performance Management, 56, 436-455.

Cheng, J. L. C., \& Kesner, I. F. (1997). Organizational slack and response to environmental shifts: The impact of resource allocation patterns. Journal of Management, 23, 1-18.

Collier, R., \& Collier, D. (1991). Shaping the political arena: Critical junctures, the labor movement, and regime dynamics in Latin America. Princeton, NJ: Princeton University Press.

Correa, M. E. (2007). Leading change in Latin America. Harvard Business Review, 85(10), 40-42.

Currie, G. (1999). The influence of middle managers in the business planning process: A case study in the UK NHS. British Journal of Management, 10, 141-155.

Daniel, F., Lohrke, F. T., Fornaciari, C. J., \& Turner, R., Jr. (2004). Slack resources and firm performance: A metaanalysis. Journal of Business Research, 57, 565-574.

Das, A., Handfield, R. B., Calantone, R. J., \& Ghosh, S. (2000). A contingent view of quality management: The impact of international competition on quality. Decision Sciences, 31, 649-690.

Davis, T. R. V. (2001). Integrating internal marketing with participative management. Management Decision, 39, 121-132.

De La Garza, E. (2007). The crisis of the Maquiladora model in Mexico. Work and Occupations, 34, 399-429.

DeSarbo, W. S., DiBenedetto, C. A., Song, S., \& Sinha, I. (2005). Revisiting the Miles and Snow strategic framework: Uncovering interrelationships between strategic types, capabilities, environmental uncertainty, and firm performance. Strategic Management Journal, 26, 47-74.

Dess, G. G., \& Davis, P. S. (1984). Porter's generic strategies as determinants of strategic group membership and performance. Academy of Management Journal, 26, 467-488.

DeWitt, J. W. (1995). Even better than in the U.S. Apparel Industry Magazine, 56(2), 36-38.

Dierickx, I., \& Cool, K. (1989). Asset stock accumulation and sustainability of competitive advantage. Management Science, 35, 1504-1511.

Dominguez-Villalobos, L., \& Brown-Grossman, F. (2007). NAFTA's impact on business environmental decision making. Policy Studies Journal, 25, 245-263.

Duimering, P. R., \& Robinson, R. B. (2009). Effects of context on team behavior. International Journal of Human Resource Development \& Management, 9, 19-35.

Dutta, S., Narasimhan, O., \& Rajiv, S. (2005). Conceptualizing and measuring capabilities: Methodology and empirical application. Strategic Management Journal, 26, 277-285.

Economist Intelligence Unit (EIU). (2003). Country profiles, 2003. London, England: Economist Intelligence Unit.

Embertson, M. K. (2006). The importance of middle managers in healthcare organizations. Journal of Healthcare Management, 51(4), 223-232.

Fiol, C. M. (1991). Managing culture as a competitive resource: An identity-based view of sustainable competitive advantage. Journal of Management, 17, 191-211.

Floyd, S. W., \& Wooldridge, B. (2000). Building strategy from the middle: Reconceptualizing strategy process. Thousand Oaks, CA: Sage.

Foss, K., \& Foss, N. (2005). Resources and transaction costs: How property rights economics furthers the resourcebased view. Strategic Management Journal, 26, 541-553.

Fulghieri, P., \& Hodrick, L. S. (2006). Synergies and internal agency conflicts: The double-edged sword of mergers. Journal of Economics \& Management Strategy, 15, 549-576.

Ghemawat, P. (2002). Competition and business strategy in the historical perspective. Business History Review, 76, 37-74.

Gibbons, R. (2003). Team theory, garbage cans and real organizations: Some history and prospects of economic research on decision-making in organizations. Industrial and Corporate Change, 12, 753-787.

Gioia, D. A., \& Chippipeddi, K. (1991). Sensemaking and sensegiving in strategic change initiation. Strategic Management Journal, 12, 433-448.

Goldman, H. H. (2003). Implementing the global strategy plan: A human issue. Strategic Direction, 19(2), 2-5.

Goll, I., \& Johnson, N. B., (1996). The role of top management demographic characteristics in employee participation programs. International Journal of Management, 13(1), 76-83. 
Graham, J. L. (2001). Culture and human resources management. Oxford Handbook of International Business, 1, 503-537.

Hambrick, D. C. (1981). Strategic awareness within top management teams. Strategic Management Journal, 2, 263-279.

Hambrick, D. C. (1983). Some tests of the effectiveness and functional attributes of Miles and Snow's strategic types. Academy of Management Journal, 26, 5-26.

Hamilton, R. T., \& Shergill, G. S. (1992). The relationship between strategy-structure fit and financial performance in New Zealand: Evidence of generality and validity with enhanced controls. Journal of Management Studies, 29, 95-113.

Hashim, M. K. (2000). Business strategy and performance in Malaysian SMEs: A recent survey. Malaysian Management Review, 35(2), 1-10.

Hawes, J. M., \& Crittendon, W. F. (1984). A taxonomy of competitive retailing strategies. Strategic Management Journal, 5(2), 275-287.

Haworth, N. (1989). Political transition and the Peruvian labor movement, 1968-1975. In E. C. Epstein (ed.) Labor Autonomy and the State in Latin America, pp. 195-218. Boston, MA: Unwin Hyman.

Hergert, M. L. (1983). The incidence and implications of strategic groupings in U.S. manufacturing industries (Unpublished doctoral dissertation). Harvard University, Cambridge, MA.

Hiam, A. (1993). Strategic planning unbound. Journal of Business Strategy, 14(2), 46-52.

Hise, R. T., Solano-Mendez, R., \& Gresham, L. G. (2003). Doing business in Mexico. Thunderbird International Business Review, 45, 211-224.

Hofstede, G. (1980). Motivation, leadership and organization: Do American theories apply abroad? Organizational Dynamics, 9, 42-63.

Hofstede, G. (1993). Cultural constraints in management theories. Academy of Management Executive, 7, 81-94.

Hofstede, G. (2003). Culture's consequences: Comparing values, behaviors, institutions, and organizations across nations. Thousand Oaks, CA: Sage.

Hofstede, G. (2004). Cultures and organizations, software of the mind (2nd ed.). New York, NY: McGraw-Hill.

Husted, B. W., \& Allen, D. B. (2006). Corporate social responsibility in the multinational enterprise: Strategic and institutional approaches. Journal of International Business Studies, 37, 838-849.

Husted, B. W. Dozier, J. B., McMahon, J. T., \& Kattan, M. W. (1996). The impact of cross-national carriers of business ethics on attitudes about questionable practices and form of moral reasoning. Journal of International Business Studies, 27, 391-411.

Ickis, J. C. (2000). Implementing globalization strategies in Latin America. Journal of Business Research, 50(1), 9-13.

Jackle, A. E., \& Li, C. A. (2006). Firm dynamics and institutional participation: A case study on informality of micro enterprises in Peru. Economic Development and Cultural Change, 54, 557-578.

Jusoh, R., \& Parnell, J. A. (2008). Competitive strategy and performance measurement in the Malaysian context: An exploratory study. Management Decision, 46, 5-31.

Katz, J. P., Zarzeski, M. T., \& Hall, H. J. (2000). The impact of strategy, industry, and culture on forecasting the performance of global competitors: A strategic perspective. Journal of Business Strategies, 17(2), 119-143.

Kay, B. H. (1997). "Fujipopulism" and the liberal state in Peru, 1990-1995. Journal of Interamerican Studies and World Affairs, 38(4), 55-99.

Kim, J., \& Mahoney, J. T. (2005). Property rights theory, transaction costs theory, and agency theory: An organizational economics approach to strategic management. Management and Decision Economics, 26, 223-242.

Kim, E., Nam, D., \& Stimpert, J. L. (2004). The applicability of Porter's generic strategies in the digital age: Assumptions, conjectures, and suggestions. Journal of Management, 30, 569-590.

Kor, Y. Y., \& Mahoney, J. T. (2005). How dynamics, management, and governance of resource deployments influence firm-level performance. Strategic Management Journal, 26, 489-496.

Kumar, S., \& Chase, C. P. (2006). Barriers and success factors in the management international operations: Mexico and China overview. International Journal of Management \& Decision Making, 7, 525-537.

Kimura, S., \& Mourdoukoutas, P. (2000). Effective integration of management control systems for competing in global industries. European Business Review, 12(1), 41-45.

Leiblein, M. J. (2003). The choice of organizational governance form and performance: Predictions from transaction cost, resource-based, and real options. Journal of Management, 29, 937-961.

Lowe, J., Morris, J., \& Wilkinson, B. (2000). British factory, Japanese factory, and Mexican factory: An international comparison of front-line management and supervision. Journal of Management Studies, 37, 541-562.

Lumpkin, G. T., \& Dess, G. G. (2006). The effect of 'simplicity' on the strategy-performance relationship: A note. Journal of Management Studies, 43, 1583-1604.

Martin-Alcazar, F., Romero-Fernandez, P., Sancez-Gardey, G., \& Sanchez-Perez, J. (2009). Team working with 
organizations: A theoretical approach drawing on the resource-based view of the firm. International Journal of Human Resource Development \&Management, 9, 81-96.

Mason, E. S. (1939. Price and production policies of large-scale enterprises. American Economic Review, 29, 61-74.

Miles, R. E., \& Snow, C. C. (1978). Organizational strategy, structure, and process. New York, NY: West.

Miles, R. E., \& Snow, C. C. (1986). Organizations: New concepts for new forms. California Management Review, 18(3), 62-73.

Miller, A., \& Dess, G. G. (1993). Assessing Porter's (1980) model in terms of its generalizability, accuracy and simplicity. Journal of Management Studies, 30, 553-585.

Ministerio de Trabajo y Promoción del Empleo (MTPE). (2003). El Empleo en el Peru: 2002-2003. Lima, Peru: Dirección Nacional del Empleo y Formación Profesional.

Mintzberg, H., \& Waters, J. A. (1985). Of strategies, deliberate and emergent. Strategic Management Journal, 6, 257-272.

Moore, M. (2005). Towards a confirmatory model of retail strategy types: An empirical test of Miles and Snow. Journal of Business Research, 58, 696-704.

Morales, O. (1997). The flip side. Business Mexico, 7(7), 32-33.

Morgan, R. E., \& Berthon, P. (2008). Market orientation, generative learning, innovation strategy and business performance interrelationships in bioscience firms. Journal of Management Studies, 45, 1329-1353.

Morris, T., \& Pavett, C. M. (1992). Management style and productivity in two cultures. Journal of International Business Studies, 23, 169-179.

Nichol, R. L. (1992). Get middle managers involved in the planning process. Journal of Business Strategy, 13(3): 26-32.

Nicholson, N., Rees, A., \& Brooks-Rooney, A. (1990). Strategy, innovation and performance. Journal of Management Studies, 27, 511-534.

O’Regan, N., \& Ghobadian, A. (2006). Perceptions of generic strategies of small and medium sized engineering and electronics manufacturers in the UK: The applicability of the Miles and Snow typology. Journal of Manufacturing Technology Management, 17, 603-620.

Ostroff, C., \& Atwater, L. E. (2003). Does whom you work with matter? Effects of referent group gender and age composition on managers' compensation. Journal of Applied Psychology, 88, 725-740.

Palmer, D. S. (1992). The shining path of Peru. New York, NY: St. Martin's Press.

Parnell, J. A. (1997). New evidence in the generic strategy and business performance debate: A research note. British Journal of Management, 8, 175-181.

Parnell, J. A. (2000). Reframing the combination strategy debate: defining forms of combination, Journal of Applied Management Studies, 9(1), 33-54.

Parnell, J.A. (2004). Variations in strategic philosophy among American and Mexican managers. Journal of Business Ethics, 50, 267-278.

Parnell, J.A. (2008). Assessing theory and practice in competitive strategy: Challenges and future directions. Journal of CENTRUM Cathedra, 1(2), 12-27.

Parnell, J. A., \& Hatem, T. (1999). Cultural antecedents of behavioral differences between American and Egyptian managers. Journal of Management Studies, 36, 399-418.

Parnell, J. A., Lester, D. L., \& Menefee, M. L. (2000). Strategy as a response to organizational uncertainty: An alternative perspective on the strategy-performance relationship. Management Decision, 38, 520-530.

Parnell, J. A., O’Regan, N., \& Ghobadian, A. (2006). Measuring performance in competitive strategy research. International Journal of Management and Decision Making, 7, 408-417.

Parnell, J. A., \& Wright, P. (1993). Generic strategy and performance: An empirical test of the Miles and Snow typology. British Journal of Management, 4(1), 29-36.

Parodi, J. (2000). To be a worker: Identity and politics in Peru. Chapel Hill, NC: University of North Carolina Press.

Pelham, A. M., \& Wilson, D. T. (1996). A longitudinal study of the impact of market structure, firm structure, strategy, and market orientation culture on dimensions of small-firm performance. Journal of the Academy of Marketing Science, 24(1), 27-43.

Pitelis, C. N., \& Pseiridis, A. N. (1999). Transaction costs versus resource value? Journal of Economic Studies, 26, 221-240.

Pongatichat, P., \& Johnston, R. (2008). Exploring strategy-misaligned performance measurement. International Journal of Productivity and Performance Management, 57(3), 207-222.

Porter, M. E. (1980). Competitive strategy. New York, NY: Free Press.

Porter, M. E. (1981). The contributions of industrial organization to strategic management. Academy of Management Review, 6, 609-620.

Porter, M .E. (1985). Competitive advantage. New York, NY: Free Press 
Proff, H. (2000). Hybrid strategies as a strategic challenge: The case of the German automotive industry. Omega, 28(5), 541.

Punnett, B. J., \& Shenkar, O. (1994). International management research: Toward a contingency approach. Advances in International Comparative Management, 9, 39-55.

Qi, H. (2005). Strategy implementation: The impact of demographic characteristics on the level of support received by middle managers. Management International Review, 45(1), 45-70.

Ray, G., Barney, J. B., \& Muhanna, W. A. (2003). Capabilities, business processes, and competitive advantage: Choosing the dependent variable in empirical tests of the resource-based view. Strategic Management Journal, 25, 23-37.

Reed, R., \& DeFillippi, R.J. (1990). Causal ambiguity, barriers to imitation, and sustainable competitive advantage. Academy of Management Review, 15, 88-102.

Rumelt, R. (1984). Towards a strategic theory of the firm. In R. Lamb (Ed.), Competitive strategic management (pp. 556-570). Englewood Cliffs, NJ: Prentice-Hall.

Saavedra, J., \& Chong, A. (1999). Structural reform, institutions and earnings from the formal and informal sectors in urban Peru. Journal of Development Studies, 35(4), 95-116.

Schilit, W. K. (1987). An examination of the influence of middle-level managers in formulating and implementing strategic decisions. Journal of Management Studies, 24, 271-293.

Schniederjans, M. J., \& Zuckweiler, K. M. (2004). A quantitative approach to the outsourcing-insourcing decision in an international context. Management Decision, 42, 974-986.

Segev, E. (1987). Strategy, strategy making and performance in a business game. Strategic Management Journal, 8, 565-577.

Sheehan, N. T., \& Foss, N. J. (2007). Enhancing the prescriptiveness of the resource-based view through Porterian activity analysis. Management Decision, 45, 450-461.

Slater, S. F., \& Narver, J. C. (1993). Product-market strategy and performance: An analysis of the Miles and Snow Strategy types. European Journal of Marketing, 27(10), 33-51.

Stephens, G. K., \& Greer, C. R. 1995. Doing business in Mexico: Understanding cultural differences. Organizational Dynamics, 24(1), 39-55.

Stinson, D. (1995, October 9) Aggressive little brewery plays giant killer in Peru's beer market. Marketing (Maclean Hunter), 100, 7.

Sully De Luque, M. F. (2000). The impact of cross-cultural differences on feedback seeking behavior: Tendency to engage, strategy type, and preferred source choice. Dissertation Abstracts International, 61(7-a), 2808.

Sully De Luque, M. F., \& Arbazia, L. A. (2005). The complexity of managing human resources in Peru. International Journal of Human Resource Management, 16, 2237-2253.

Thakur, M. (1998). Involving middle managers in strategy making. Long Range Planning, 31, 732-741.

Thompson, J. D. (1967). Organizations in action. New York, NY: McGraw-Hill.

Verreynne, M. (2006). Strategic-making processes and firm performance in small firms. Journal of Management and Organization, 12(3), 209-222.

Whinston, M. D. (2003). On the transaction cost determinants of vertical integration. Journal of Law, Economics \& Organization, 19(1), 1-24.

White, R. E. (1986). Generic business strategies, organizational context, and performance: An empirical investigation. Strategic Management Journal, 7, 217-231.

Wooldridge, B., \& Floyd, S. W. (1990). The strategy process, middle management involvement, and organizational performance. Strategic Management Journal, 11, 231-241.

Wright, P. (1987). A refinement of Porter's strategies. Strategic Management Journal, 8, 93-101.

Yoo, J. W., Reed, R., Shin, S. J., \& Lemak, D. J. (2009). Strategic choice and performance in late movers: Influence of the top management team's external ties. Journal of Management Studies, 46, 308-335.

Zahra, S. A., \& Pearce, II, J. A. (1990). Research evidence on the Miles and Snow typology. Journal of Management, 16, 751-768.

Zajac, E. J., Kraatz, M. S., \& Bresser, R. K. F. (2000). Modeling the dynamics of strategic fit: A normative approach to strategic change. Strategic Management Journal, 21, 429-453.

* Correspondence concerning this article should be directed to John Parnell at: john.parnell@uncp.edu 